\title{
It is elemental: soil nutrient stoichiometry drives bacterial diversity
}

DOI:

10.1111/1462-2920.13642

\section{Document Version}

Accepted author manuscript

Link to publication record in Manchester Research Explorer

\section{Citation for published version (APA):}

Delgado-Baquerizo, M., Reich, P. B., Khachane, A. N., Campbell, C., Thomas, N., Freitag, T. E., Al-Soud, W. A., Sorensen, S., Bardgett, R., \& Singh, B. K. (2017). It is elemental: soil nutrient stoichiometry drives bacterial diversity. Environmental microbiology, 19, 1176-1188. https://doi.org/10.1111/1462-2920.13642

\section{Published in:}

Environmental microbiology

\section{Citing this paper}

Please note that where the full-text provided on Manchester Research Explorer is the Author Accepted Manuscript or Proof version this may differ from the final Published version. If citing, it is advised that you check and use the publisher's definitive version.

\section{General rights}

Copyright and moral rights for the publications made accessible in the Research Explorer are retained by the authors and/or other copyright owners and it is a condition of accessing publications that users recognise and abide by the legal requirements associated with these rights.

\section{Takedown policy}

If you believe that this document breaches copyright please refer to the University of Manchester's Takedown Procedures [http://man.ac.uk/04Y6Bo] or contact uml.scholarlycommunications@manchester.ac.uk providing relevant details, so we can investigate your claim.

\section{OPEN ACCESS}




\section{It is elemental: soil nutrient stoichiometry drives bacterial diversity.}

Manuel Delgảdo-Baquerizo ${ }^{1,2^{*}}$, Peter B. Reich ${ }^{1,3}$, Amit N. Khachane ${ }^{1}$, Colin D. Campbell ${ }^{4}$, Nadine Thomas $^{4}$, Thomas E. Freitag ${ }^{4}$, Waleed Abu Al-Soud ${ }^{5}$, Søren Sørensen ${ }^{5}$, Richard D. Bardgett ${ }^{6}$ and Brajesh K. Singh ${ }^{1,7^{*}}$

${ }^{1}$ Hawkesbury Institute for the Environment, Western Sydney University, Penrith, 2751, New South Wales, Australia.

${ }^{2}$ Cooperative Institute for Research in Environmental Sciences, University of Colorado, Boulder, CO 80309.

${ }^{3}$ Department of Forest Resources, University of Minnesota, St. Paul, MN 55108, USA.

${ }^{4}$ The James Hutton Institute, Craigiebuckler, Aberdeen AB15 8QH, UK.

${ }^{5}$ Department of Food Science, University of Copenhagen, Frederiksberg, Denmark.

${ }^{6}$ School of Earth and Environmental Sciences, Michael Smith Building, The University of Manchester, Oxford Road, Manchester M13 9PT, UK.

${ }^{7}$ Global Centre for Land-Based Innovation, Western Sydney University, Penrith South DC, NSW 2751, Australia.

\section{*Authors for correspondence:}

Manuel Delgado-Baquerizo. E-mail: M.DelgadoBaquerizo@gmail.com

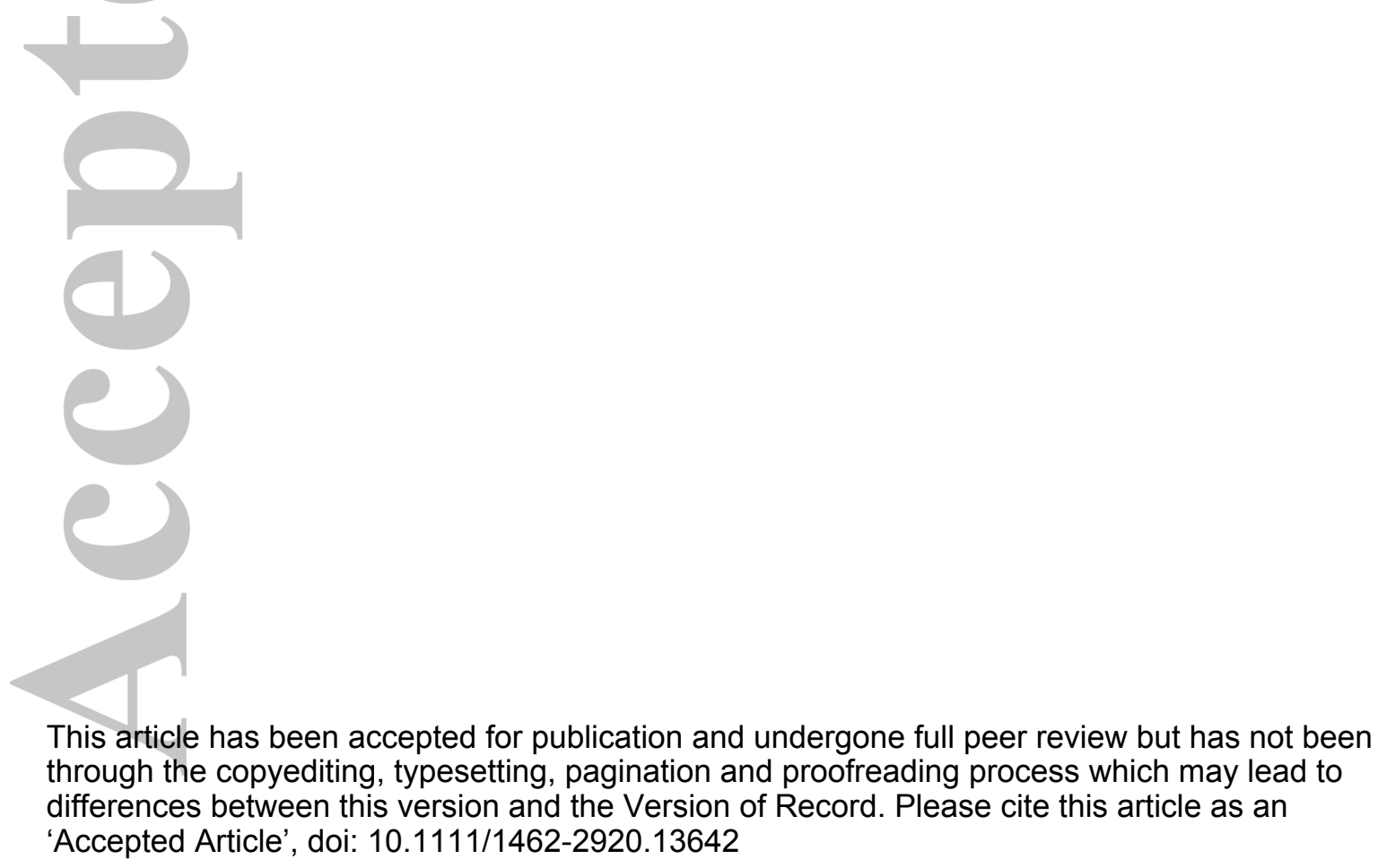




\section{Summary}

It is well established that resource quantity and elemental stoichiometry play major roles in shaping below and aboveground plant biodiversity, but their importance for shaping microbial diversity in soil remains unclear. Here, we used statistical modeling on a regional database covering 179 locations and six ecosystem types across Scotland to evaluate the roles of total carbon (C), nitrogen (N) and phosphorus $(\mathrm{P})$ availabilities and ratios, together with land use, climate and biotic and abiotic factors, in determining regional scale patterns of soil bacterial diversity. We found that bacterial diversity and composition were primarily driven by variation in soil resource stoichiometry (total C:N:P ratios), itself linked to different land uses, and secondarily driven by other important biodiversity drivers such as climate, soil spatial heterogeneity, soil $\mathrm{pH}$, root influence (plant-soil microbe interactions) and microbial biomass (soil microbe-microbe interactions). In aggregate, these findings provide evidence that nutrient stoichiometry is a strong predictor of bacterial diversity and composition at a regional scale.

Key words. Carbon cycle, Nitrogen cycle, Phosphorus cycle, Terrestrial ecosystems, Biodiversity, Bacteria, Ecological stoichiometry. 


\section{Introduction}

Soil bacterial communities are among the most abundant and diverse on Earth, and are responsible for key ecosystem processes, including decomposition, nutrient cycling, and detoxification (van der Heijden et al., 2008; Jing et al., 2015; Delgado-Baquerizo et al., 2016a). Many of these functions are also critical for ecosystem services, such as primary production and water purification (van der Heijden et al., 2008; Bardgett and van der Putten 2014). Despite the importance of these soil microbial communities for human well-being, we lack both a theoretical framework and solid empirical data to explain bacterial diversity patterns in terrestrial ecosystems (Waldrop et al., 2006; Bardgett and van der Putten 2014). Several prominent ecological theories emphasize the important role of resource supply and competition driving the diversity of plants and animal in terrestrial ecosystems (Tilman 1982; Hooper et al., 2000; Sterner and Elser 2002). Similarly, it has been proposed that plant and soil animal diversity (e.g. plant consumer) are positively related to resource quantity and heterogeneity due to greater niche differentiation (Hooper et al., 2000; Bardgett et al., 2005; Sardans et al., 2012), with growing support from empirical evidence (Hooper et al., 2000; Wardle 2006; Sardans et al., 2012). Surprisingly, there is a lack of knowledge about how bacterial communities relate to resource quantity and stoichiometry in terrestrial ecosystems; and no regional studies have been conducted on this topic yet.

Soil elemental stoichiometry is a major driver of organic matter decomposition and nutrient cycling in terrestrial ecosystems; processes that are largely conducted by microbial communities (Zechmeister-Boltenstern et al., 2015 for review). For instance, substrate carbon-to-nitrogen ratio is one of the main factors regulating critical microbial processes such as nutrient mineralization and immobilization in terrestrial ecosystems (Zechmeister-Boltenstern et al., 2015). However, we lack a system-level perspective including how key ecological drivers such as the quantity and stoichiometry of total carbon $(\mathrm{C})$, nitrogen $(\mathrm{N})$ and phosphorus $(\mathrm{P})$ relate to soil bacterial diversity and composition. Climate change and human management are altering soil elemental stoichiometry in terrestrial ecosystems worldwide (Peñuelas et al., 2012; Delgado-Baquerizo et al., 2013); and thus, assessing how variations in soil elemental stoichiometry may affect the microbial diversity and composition is critical for our understanding of ecosystem functioning under changing environments, and for formulating sustainable management and conservation policies.

Bacterial communities often obtain their energy from the soil organic matter (e.g. organic matter decomposition and mineralization) (Hooper et al., 2000; Wardle 2006; Zechmeister-Boltenstern et al., 2015), and the elemental stoichiometry (e.g., C:N, N:P and C:P ratios) of soil organic matter may influence the composition and diversity of these microorganisms in terrestrial ecosystems. Following 
the growth-rate hypothesis (Sterner and Elser 2002), fast-growing organisms such as bacteria require high demand for P (i.e. ribosomes, ATP, DNA and RNA; Peñuelas and Sardans 2009), and are characterized by a low C:P stoichiometry (e.g. vs. plants; Peñuelas and Sardans 2009; ZechmeisterBoltenstern et al., 2015). In this respect, if diversity mirrors productivity within bacterial communities, $\mathrm{P}$ supply might drive bacterial diversity. While $\mathrm{C}$ and $\mathrm{N}$ are relatively easy to obtain from the atmosphere for some microbial communities (photosynthesis and $\mathrm{N}$-fixation), the availability of $\mathrm{P}$ is largely bounded to the bedrock (McGill and Cole 1981). Thus, environments with high P and low C:P ratios (e.g. young soils or those of agricultural vs. natural ecosystems) may support a high microbial diversity (Fig. 1). On the other hand, soils with low $\mathrm{P}$ and high C:P ratios (e.g. old soils or those of natural vs. agricultural ecosystems) may constrain the diversity of these microbial communities by leading to high competition-to-exclusion between microbial species and to the consequent reduction in diversity (Fig. 1; Tilman 1982; Waldrop et al., 2006; Wardle 2006). Alternatively, highly productive systems, especially those modified by agriculture, may have less diversity due to high human disturbance.

Here we tested whether resource quantity (i.e. total $\mathrm{C}, \mathrm{N}$ and $\mathrm{P})$ and stoichiometry $(\mathrm{C}: \mathrm{P}, \mathrm{N}: \mathrm{P}$ and $\mathrm{C}: \mathrm{N}$ ratios) can explain variations in soil bacterial diversity (i.e. alpha diversity) and community composition (i.e. beta diversity) in terrestrial ecosystems at a regional scale, and compare their effects to other hypothesized influences. Previous studies have explored the relationship between microbial diversity and proxies of nutrient availability (e.g., inorganic $\mathrm{N}$ and $\mathrm{P}$ concentrations in soil solution; Jing et al., 2015; Delgado-Baquerizo et al., 2016a). Inorganic pools reflect the difference between gross mineralization driven by microbial activity and uptake by microbes and plants, and represent a very small percentage of total $\mathrm{N}$ and $\mathrm{P}$ (usually $<1 \%$ ). Here instead, we explore the relationship between total $\mathrm{C}, \mathrm{N}$ and $\mathrm{P}$ and bacterial diversity. While microbial composition and diversity may drive the soil solution pools of inorganic $\mathrm{N}$ and $\mathrm{P}$ via mineralization processes, they will unlikely drive total soil $\mathrm{C}, \mathrm{N}$ and $\mathrm{P}$ which are linked to long-term plant productivity, $\mathrm{N}$ fixation and bedrock availability in the case of total P (McGill and Cole 1981). As a consequence, total C, N and P are potential drivers of microbial diversity more than they are regulated by this diversity. We predicted that conditions that favor the dominance of fast-growing soil bacteria, such as relatively low total $\mathrm{C}$ and low $\mathrm{C}: \mathrm{N}, \mathrm{N}: \mathrm{P}$ and $\mathrm{C}: \mathrm{P}$ ratios, would promote their diversity (Hooper et al., 2000; Peñuelas and Sardans 2009; ZechmeisterBoltenstern et al., 2015). Similarly, different bacterial communities may be adapted to different availability of $\mathrm{C}, \mathrm{N}$ and $\mathrm{P}$ in soil, and thus changes in soil $\mathrm{C}: \mathrm{N}: \mathrm{P}$ ratios and availability will alter their composition among different terrestrial ecosystems. In this paper, we used structural equation modeling (SEM) to build a system-level understanding of the key abiotic (e.g. soil pH and spatial heterogeneity; 
Fierer et al., 2009; Lauber et al., 2009; Ranjard et al., 2013) and biotic (microbial biomass and plant roots; Waldrop et al. 2006; Maestre et al. 2015) drivers of bacterial diversity in order to gain a more comprehensive understanding of the role of soil elemental stoichiometry in driving the diversity of soil bacteria in terrestrial ecosystems. In doing so, we seek to further our capacity to predict how complex soil microbial communities will respond to future global change, including land use intensity and climate change (Bardgett and van der Putten 2014; Maestre et al., 2015).

\section{Results}

\section{Relationship between soil chemistry and elemental stoichiometry with bacterial diversity}

Total C was negatively related to total P in soil (Fig. S1), however, both total C (Fig. S1) and P (Fig. $\mathrm{S} 1$ ) were positively related to total N. In addition, C:P ratio was highly related to both N:P (Fig. S1) and C:N (Fig. S1) ratios in soil, and C:N ratio was strongly related to N:P ratio (Fig. S1).

Across all sites, soil bacterial diversity was negatively related to total $\mathrm{C}$ and the ratios of $\mathrm{C}: \mathrm{P}$, $\mathrm{N}: \mathrm{P}$ and C:N (Fig. 2), and positively related to total P (Fig. 2e). Soil bacterial diversity was not related to total soil N (Fig. 2b). Similar results were found when we explored the relationship between total C, $\mathrm{N}$ and $\mathrm{P}$ uncorrected for bulk density and bacterial diversity (Fig. S2), although the bulk density correction changed the relative strength of effects. Moreover, we found similar results when exploring the relationship between $\mathrm{C}, \mathrm{N}$ and $\mathrm{P}$ concentration and ratios and the residuals of bacterial diversity (residuals of the relationship between soil depth and bacterial diversity) in our study sites. (Fig. S3).

Our SEM explained $57 \%$ of the variance in the soil bacterial diversity. When including both direct (proximate) and indirect (ultimate) effects, soil total P (+), organic matter (-), and land use intensity $(+)$ were the most important drivers controlling soil bacterial diversity at a regional scale (Fig. 3a). Similar results were found when we explicitly included bulk density and uncorrected values (i.e. by bulk density) for C, N and P in our model (Figs. S4 and S5). Interestingly, land use intensity did not show any direct effect on bacterial diversity (Fig. 3a). Thus, all effects from land use intensity on bacterial diversity were indirectly accounted for via total $\mathrm{P}$, organic matter, and soil pH (Fig. 3a). In particular, land use intensity showed a direct negative effect on soil organic matter (Fig. 3; Fig. S6), but a direct positive effect on soil total P (Fig. 3; Fig. S6), which together had a total positive effect on soil bacterial diversity (Fig. 3b; Fig. S7). Soil pH showed direct positive effects on soil bacterial diversity (Fig. 3a), however this variable itself is highly driven by land use intensity, the amount of soil organic matter and total P in soil (Fig. 3a). We did not find any effects of soil spatial heterogeneity, microbial biomass (microbe-microbe interaction) and root influence (plant-microbe interaction) on the soil bacterial diversity (Fig. 3a). Overall, total standardized effects (sum of direct and indirect effects from 
each single variable) from SEM suggest that soil total $\mathrm{P}, \mathrm{pH}$, total $\mathrm{C}$, and climate (in that order) were the most important drivers of soil bacterial diversity (Fig 3a). Soil total $\mathrm{C}$ and total $\mathrm{P}$ showed total negative and positive effects on soil bacterial diversity, respectively (Fig. 3a and b). Moreover, total N showed a total positive effect on bacterial diversity.

Regarding distance-based multi-model inference, the best-fitting models accounted for over $57 \%$ of the variation in soil bacterial diversity; and always included resource quantity and stoichiometry as predictor variables (Table S1). Further, the same models without resource quantity and stoichiometry had a higher AICc $(>20)$ indicating that resource quantity and stoichiometry provide unique information to predict soil bacterial diversity. In agreement with the results in Table S1, variation partitioning modeling provided further evidence that resource quantity and stoichiometry explain a unique portion of the variance of soil bacterial diversity, which was not explained by other land use and environmental predictors (Fig. 4).

\section{Relationship between soil chemistry and elemental stoichiometry with bacterial composition}

Bacterial communities were dominated by Acidobacteria, Actinobacteria, Chloroflexi and $\alpha$ Proteobacteria (Fig. S9). Our db-RDA analyses indicate that changes in C, N and P availabilities and $\mathrm{C}: \mathrm{N}: \mathrm{P}$ ratios, as a consequence of land use, can also alter soil bacterial composition at the OTUs level (Fig. S8). Moreover, similar to what was found for bacterial diversity, our variation partitioning modeling indicated that resource quantity and stoichiometry explain a unique portion of the variance of soil bacterial community composition at the OTU level (Fig. 4). Regarding, individual taxa, we found that the relative abundance of Chloroflexi and Firmicutes decreased in parallel with increasing soil C:P, $\mathrm{N}: \mathrm{P}$ and $\mathrm{C}: \mathrm{N}$ ratios, while the opposite pattern was observed for $\alpha$-Proteobacteria, Acidobacteria, Plactomycetes and Spirochaetes (Fig. 5; Table S2). Structural equation modeling provided further evidence that the relationship between soil organic matter and total $\mathrm{P}$ and main bacterial taxa are maintained (directly or indirectly via soil drivers) after accounting for multiple drivers of microbial composition such as land use, climate, soil $\mathrm{pH}$, microbial biomass, root influence and soil spatial heterogeneity (Fig. S10). In particular, total P directly affected the relative abundance of Firmicutes, Planctomycetes and Spirochaetes, but indirectly regulated the relative abundance of Chloroflexi and $\alpha-$ Proteobacteria via soil pH (Fig. S10). Soil organic matter directly controlled the relative abundance of Firmicutes, Acidobacteria, Chloroflexi and $\alpha$-Proteobacteria, and indirectly affected the relative abundance of Planctomycetes and Spirochaetes via changes in total P (Fig. S10). Total C or P were the main drivers of Acidobacteria, Chloroflexi, Planctomycetes and Spirochaetes (Fig. S11). In particular, total $\mathrm{P}$ showed the highest total negative effect (sum of direct and indirect effects from SEM) on the 
relative abudance of Planctomycetes and Spirochaetes (Fig. S11); and total C showed the highest positive effect on Acidobacteria, and the highest negative total effect on the relative abundance of Chloroflexi (Fig. S11). Soil pH (negative) and land use intensity (positive) were the main driver of $\alpha$ Proteobacteria, and Firmicutes (Fig. S11).

\section{Discussion}

Our results demonstrate, for the first time, that the diversity of soil bacteria peaks under conditions of high $\mathrm{P}$ availability (which is key for the production of ribosomes, ATP, DNA and RNA to support fast growth rates), relatively low total $\mathrm{C}$, and low ratios of $\mathrm{C}: \mathrm{N}, \mathrm{N}: \mathrm{P}$, and $\mathrm{C}: \mathrm{P}$. Following our conceptual framework (Fig. 1), soils with high $\mathrm{P}$ may support a high microbial diversity as some microbes can fulfill their $\mathrm{C}$ and $\mathrm{N}$ requirement fixing these elements from the atmosphere (Fig. 1). However, low soil $\mathrm{P}$ lessens bacterial diversity as a consequence of the competition-to-exclusion driven via $\mathrm{P}$, which is derived almost exclusively from the bedrock. Moreover, high resource quality (i.e. often low C:N, N:P and $\mathrm{C}: \mathrm{P}$ ratios) can in theory lead to a greater variety of resources for bacterial communities, enhancing their diversity by promoting greater niche differentiation (Hooper et al., 2000). Altogether, our findings provide empirical evidence that, as previously hypothesized for soil animal diversity (e.g. decomposers and detritivores) (Hooper et al. 2000), resource stoichiometry can also influence bacterial diversity in terrestrial environments.

Although we found that bacterial diversity was strongly and positively related to low $\mathrm{C}$ and high $\mathrm{P}$ availability, and to elemental stoichiometry of $\mathrm{C}, \mathrm{N}$ and $\mathrm{P}$, these are bivariate correlations, and hence, potentially not causative relations. To address this issue, we used the principles of structural equation modeling (SEM) to jointly evaluate the multiple disparate hypotheses so as to build a systemlevel understanding of the drivers of bacterial diversity. After accounting for multiple soil drivers of bacterial diversity, our SEM provided evidence that soil total P $(+$ ), organic matter (total $\mathrm{C}$ and $\mathrm{N}$ ) and land use intensity were the most important drivers controlling soil bacterial diversity at a regional scale. Moreover, variation partitioning modeling provided further evidence that resource quantity and stoichiometry explain a unique portion of the variation in bacterial diversity and community composition (at the OTU level) which is not explained by other important land use and environmental predictors.

The increase in $\mathrm{C}: \mathrm{P}$ and total $\mathrm{C}$, but decrease in total $\mathrm{P}$, contrasting high to low intensity human managed ecosystems observed here, and by others (Xu et al., 2013), and the decrease in bacterial diversity with increasing $\mathrm{C}: \mathrm{P}$ ratios, parallels what might be expected during long-term ecosystem development. Although this progression has been described at the geological time scale (thousands to millions of years), and changes in land use from natural to arable and improved grasslands occur at the 
ecological time scale (years to hundreds of years), both contrasts may share the same biogeochemical signatures in terms of resource C:N:P stoichiometry's and soil bacterial diversity (McGill and Cole 1981; Jangid et al., 2014). Thus, although $\mathrm{C}$ and $\mathrm{N}$ accumulate in natural ecosystems with soil development, $\mathrm{P}$, which is mainly supplied by the parent material, is progressively depleted and immobilized in plants and animal tissues and overtime becomes available in insufficient concentrations for microbes (McGill and Cole 1981), which may limit the diversity of fast growing microorganisms such as bacteria (McGill and Cole 1981; Jangid et al., 2014). Contrary to this, P becomes available in human managed ecosystems due to soil erosion (e.g. because of bedrock rejuvenation) and inorganic fertilization. Therefore, total $\mathrm{C}$ and $\mathrm{N}$ are largely reduced in human perturbed ecosystems, but these elements are still available for some microbes from biological processes such as photosynthesis and $\mathrm{N}$ fixation. Interestingly, total $\mathrm{N}$ showed a total positive effect on bacterial diversity in our SEM, which may be linked to the use of inorganic fertilizers in human managed systems (i.e. improved grasslands) and to the lowest $\mathrm{N}$ availability in low managed ecosystems such as bogs (Fig. S6). The matching relatively high availability of $\mathrm{C}, \mathrm{N}$ and $\mathrm{P}$ for bacterial communities in soils perturbed by human activities may explain the highest bacterial diversity under high disturbance conditions (low vs. high intensity human managed ecosystems).

Altogether our findings provide evidence that soil factors such as high disturbance intensity (human managed vs. natural ecosystems), relatively low total C, high P and low C:N, N:P and C:P ratios, which often promote the abundance of bacterial relative to fungi (Bardgett and McAlister 1999; Peñuelas and Sardans 2009; De Vries et al., 2012), can also enhance the diversity of soil bacteria. These conditions often promote the fast cycling of nutrients and high productivity environments (Peñuelas and Sardans 2009; Delgado-Baquerizo et al., 2013). Moreover, a reduction in soil organic matter content and a decrease in $\mathrm{C}: \mathrm{P}, \mathrm{N}: \mathrm{P}$ and $\mathrm{C}: \mathrm{N}$ ratios with land use intensity has been reported to reduce the abundance of other microbial groups, such as fungi, likely reducing the competition on bacteria (i.e. competition-to-exclusion; Waldrop et al., 2006; van der Heijden et al., 2008). All these factors may strongly benefit the diversity of fast-cycling organisms such as bacteria, further explaining our results.

It is important to note that soils included in this study are relatively high in carbon content (Chapman et al., 2013). In this respect, the negative relationship observed here between total $\mathrm{C}$ and bacterial diversity may not necessarily occur for carbon-poor soils (e.g. arid regions). For instance, Maestre et al. (2015) found a positive relationship between soil total carbon and bacterial diversity in drylands. Contrary to what occur in highly organic soils from Scotland (average soil total $\mathrm{C}=25.7 \%$ ), carbon is a main limiting factor for microbial activity in drylands (average soil total $\mathrm{C}=1.6 \%$; Maestre 
et al. 2015) explaining the differences in the direction of the relationship between total carbon and bacterial diversity reported here and by Maestre et al. (2015). Even the arable soils included in the Scotland dataset, had total soil carbon $(2.90 \%)$ almost twice than dryland soils from Maestre et al. (2015). For this reason, the description of low carbon in this study is low in a relative sense only.

Regarding bacterial composition, our results indicate that changes in $\mathrm{C}, \mathrm{N}$ and $\mathrm{P}$ availabilities and $\mathrm{C}: \mathrm{N}: \mathrm{P}$ ratios, as a consequence of land use, can alter bacterial composition in soil (Fig. 5; Figs. S811 and Table S2). For example, the relative abundance of Chloroflexi and Firmicutes decreased in parallel with increasing soil C:P, N:P and C:N ratios, while the opposite pattern was observed for $\alpha$ Proteobacteria, Acidobacteria, Plactomycetes and Spirochaetes (Fig. 4; Table S2). A plausible explanation for this result is that bacterial phyla such as Chloroflexi and Firmicutes likely belong to old bacterial phyla which evolved in a young Earth characterized by a strongly mineral soil low in soil C. Thus, these microbial taxa may prefer low C:P and C:N ratios environments as supported by our results (Battistuzzi and Hedges 2009). Contrary to this, bacteria phyla such as Proteobacteria, Acidobacteria, Plactomycetes and Spirochaetes are likely to be comparatively young phyla which may have evolved in organic soils with a high C:P and C:N ratios (Fig. 4; Table S2) as they have a large capacity to degrade a range of organic $\mathrm{C}$ compounds from labile to recalcitrant (Battistuzzi and Hedges 2009; Trivedi et al., 2013). Alternatively, some bacterial taxa such as Chloroflexi may outcompete other phyla such as Acidobacteria under low $\mathrm{C}$ conditions, due to their ability to survive desiccation and low nutrient availability conditions (Battistuzzi and Hedges 2009; Maestre et al. 2015). Of course, it is likely that changes in total $\mathrm{C}, \mathrm{N}$ and $\mathrm{P}$ in our study are also driven by direct effects of land use intensity, which in turn, indirectly influences the relative abundance of microbial taxa in our soils (Figs. S8-11). We acknowledge that our interpretations, which are based on observational data, have limitations. While SEM allows some of the hypothesized connections to be evaluated and falsified, other assumptions are inherent (e.g., directionality of influence). Also, the models evaluated are approximations of the true system and variables omitted from the analysis could have important consequences for our findings. However, we believe that our study provides a useful summary of existing relationships and also a strong framework toward further advancing our understanding of the importance of resource quantity and stoichiometry in shaping soil bacterial diversity and composition.

Finally, soil $\mathrm{pH}$ was positively related to soil bacterial diversity (Fig. 2; Spearman's $\rho=0.726$; $\mathrm{P}<0.001$ ). Soil $\mathrm{pH}$ has been considered the best driver of soil bacterial diversity at continental and global scales (Fierer et al., 2009; Lauber et al 2009; Delgado-Baquerizo et al. 2016b), however, soil pH can be the result of many factors such as the degree of accumulation of organic matter and minerals in soil as supported by our SEM (Fig. 3). For example, soil acidification can happen with increasing 
organic matter (e.g. humic and fulvic acids) concentration (Adams et al., 2012). On the contrary, human activities such as agriculture and pasture alter soil $\mathrm{pH}$; agronomic practices, and especially liming, directly increase soil $\mathrm{pH}$. Moreover, tilling practices usually bring back parent material to the soil surface, which may contain minerals such as carbonates (e.g. calcium and magnesium carbonate) and apatite (calcium phosphate) that increase soil pH (Table S3). Our study suggest that the effects of soil pH on bacterial diversity (Fierer et al., 2009; Lauber et al 2009) is, indeed, the result of the direct impact of parent material and organic matter on this variable, which should be explicitly considered for the development of future theoretical framework and simulation models.

\section{Conclusions}

In conclusion, our findings provide evidence that resource stoichiometry is an important driver of bacterial diversity in terrestrial ecosystems at a regional scale. Bacterial diversity peaked under high $\mathrm{P}$ availability, reduced soil organic matter and low C:N, N:P and C:P ratios, which often define favorable conditions for bacterial-dominated communities. These results further indicate that resource stoichiometry provides a unifying theory of biodiversity for both above and belowground communities, and improve our understanding on the main drivers that control bacterial diversity and composition in soil environments. Taken together, our results offer a novel integrative view of the factors that drive bacterial diversity and composition from natural to human perturbed ecosystems. This knowledge is critical for formulating sustainable natural resource management and conservation policies for microbial diversity.

\section{Methods}

Soil sampling and soil properties.

To test our hypotheses, we used a regional database (National Soils Inventory of Scotland 2 [NSIS]; Lilly et al., 2010) covering 179 locations and six ecosystem types (bog, moorland, semi-natural grassland, forest, arable and improved grassland) across Scotland. Using a gradient of ecosystem types, including both low and high intensity human managed ecosystems, at a regional scale provides a unique opportunity to explore the role of resource quantity and stoichiometry controlling bacterial diversity and composition in terrestrial ecosystems. Beyond $\mathrm{C}, \mathrm{N}$ and $\mathrm{P}$ availabilities and ratios, the NSIS database provides valuable information on key drivers of microbial diversity such as land use, climate (mean annual temperature and precipitation), soil spatial heterogeneity, microbial biomass, plant root influence and soil properties (e.g. $\mathrm{pH}$ ), which allow us to evaluate the relative importance of 
resource quantity and stoichiometry vs. other well-known environmental drivers on bacterial diversity and composition at a regional scale.

Field data were collected in each location across Scotland, using a 20 x $20 \mathrm{~km}^{2}$ sampling grid during 2006-2009. Each site included a central pit under the most representative plant community. One bulked soil sample was collected from the mid-point in the upper-most horizon of soil (average of $14.99 \pm 0.34 \mathrm{~cm}$ ) under this central pit. In addition, four other replicates were taken at random orientation and at distances of 4, 8, 16 and $20 \mathrm{~m}$ from the central pit and used here to calculate the spatial heterogeneity of our plots (Appendix S1). Field moist soils were sieved to $<4 \mathrm{~mm}$ and visible pieces of plant material, and soil animals were removed before use. The details and protocols for soil sampling and profile description are given in Lilly et al., 2010. Each sample was separated into three portions. The first portion was air dried for chemical analysis. The second portion was stored at $4{ }^{\circ} \mathrm{C}$ for biochemical analyses. The third portion was stored at $-20^{\circ} \mathrm{C}$ until DNA extractions were performed. The former portion only corresponds to the samples collected under the central pit of each plot.

\section{Climate and soil predictors}

Mean annual precipitation (MAP) and temperature (MAT) were obtained in the same manner using interpolations provided by Worldclim (http://www.worldclim.org/; Hijmans et al., 2005). Observed temperature and precipitation were highly related to MAT (Spearman $\rho=0.76 ; \mathrm{P}<0.001$ ) and MAP (Spearman $\rho=0.89 ; \mathrm{P}<0.001$ ), respectively. We used MAP and MAT instead of observed temperature and precipitation, as it is likely that microbial assembly across different sites is rather influenced by long-term climatic conditions than by annual cycling (e.g., Andam et al., 2016). We determined $\mathrm{pH}$ in water on a 3:1 (water: soil) in all the soil samples with a $\mathrm{pH}$ meter. We used glucose substrate induced respiration (SIR-glucose) as our proxy of soil microbial biomass (Campbell et al., 2003). Soil spatial heterogeneity (based on the coefficient of variation of total, C, N, P and pH) and plant root influence (NMDS axes based on measurements of depth, frequency and size of plant roots) were measured as explained in Appendix S1.

\section{Total $C, N$ and $P$ measurements.}

Total C and N was analyzed in a Flash EA 1112 Series Elemental Analyser connected via a Conflo III to a DeltaPlus XP isotope ratio mass spectrometer (all Thermo Finnigan, Bremen, Germany). Soil total $\mathrm{P}$ was measured by using sodium hydroxide fusion method (Smith and Bain 1982). Because of the huge differences in soil density (Fig. S12) among land uses, we considered this when calculating soil $\mathrm{C}, \mathrm{N}$ and $\mathrm{P}$ (expressed as $\mathrm{Kg} \mathrm{ha}^{-1}$ ). Soil total $\mathrm{C}, \mathrm{N}$ and $\mathrm{P}$ stocks were calculated to $10 \mathrm{~cm}$. As total C, N and $\mathrm{P}$ content and bulk density were measured on samples taken from the mid-point in the upper-most horizon, there was an assumption that they were representative of the whole horizon.

\section{Wiley-Blackwell and Society for Applied Microbiology}

This article is protected by copyright. All rights reserved. 


\section{Bacterial diversity.}

We characterized bacterial diversity (Shannon) and composition in the soil samples from NSIS by using amplicon 454 pyrosequencing and the 341F/806R (Herlemann et al., 2011) primer set (see details in Appendix S1). Shannon diversity was selected as our metric for alpha diversity because it is highly recommended when analyzing microbial diversity (Haegeman et al., 2013).

\section{Statistical analyses}

We first explored the relationship between the availability and stoichiometry of $\mathrm{C}, \mathrm{N}$ and $\mathrm{P}$ on soil bacterial diversity and main bacterial phyla/classes using linear regressions. Carbon, $\mathrm{N}$ and $\mathrm{P}$ availability and stoichiometry data were $\log _{10}$-tranformed to achieve normality before conducting these analyses. We also conducted correlations (Spearman) between different total C:N:P concentrations and ratios with the relative abundance of the main bacteria phyla and Proteobacteria classes in this study.

\section{Soil depth.}

In this study, we collected our soil samples based on a horizon approach instead of collecting samples to a particular soil depth. The logic behind this approach is that in organic soils, comparing similar horizons among different sites may be more accurate than simply comparing similar depth. In order to further take into account the biases derived from collecting soil samples at different depth (average of $14.99 \pm 0.34 \mathrm{~cm}$ ), we repeated the linear regressions between $\mathrm{C}, \mathrm{N}$ and $\mathrm{P}$ availabilities and ratios with bacterial diversity (Fig. 1), but using the residuals of the relationship between bacterial diversity and depth instead of bacterial diversity itself. By doing this, we aim to correct any bias derived from different soil depths on our bacterial diversity index.

PERMANOVA analyses.

Differences for bacterial communities, C, N, P availability and ratios were tested among different land uses. To do this, and because our data was not normally distributed, we used a one-way semiparametric PERMANOVA (Anderson 2001), with land use as a fixed factor. In addition, because the soil samples in the NSIS were collected from the upper-most horizon of soil, we use soil depth as a covariable in each PERMANOVA analysis in order to correct any bias in our results derived from the different depth of each sample.

\section{Structural equation modeling (SEM).}

We used structural equation modeling (SEM) (see Appendix S1 for details) to evaluate a hypothesized network of linkages among key drivers of bacterial diversity (Fig. S13). For instance, we know that land use and climate will influence soil total C, N and P (McGill and Cole 1981). Similarly, total C, N and $\mathrm{P}$, which are the result of long-term biological fixation $(\mathrm{C}$ and $\mathrm{N})$ and bedrock availability (P; McGill and Cole 1981) may drive bacterial diversity but this relationship may unlikely in the opposite

\section{Wiley-Blackwell and Society for Applied Microbiology}

This article is protected by copyright. All rights reserved. 
direction. This is especially true for total $\mathrm{P}$ that almost entirely comes from the bedrock (McGill and Cole 1981). One useful characteristic of SEM for our purposes here is its utility for partitioning direct and indirect effects that one variable may have on another, and estimate the strengths of these multiple effects. Unlike regression or ANOVA, SEM offers the ability to separate multiple pathways of influence and view them as parts of a system, and thus is useful for investigating the relationship complex networks found in natural ecosystems (Grace 2006).

We included in this model bacterial diversity or main microbial taxa (response variables) and important direct and indirect predictors of biodiversity such as precipitation and temperature (lumped as climate for graphical simplicity but not lumped in analyses), land use intensity (a categorical continuous variable including two levels of human management and soil disturbance, namely low intensity, which included bog and moorland, forest and semi natural grasslands, and high intensity, which included agriculturally improved grassland and arable), climate (mean annual temperature and precipitation) soil organic matter (a composite variable of total $\mathrm{C}$ and $\mathrm{N}$ ), soil $\mathrm{P}$ content, plant root influence (plant-soil microbe interaction), microbial biomass (soil microbe-microbe interaction), soil $\mathrm{pH}$ and soil spatial heterogeneity (Appendix S1). MAP, total C, N, P, microbial biomass, and $\mathrm{pH}$ were log-transformed, and MAT was squared to improve normality. Note that the use of composite variables does not alter the underlying SEM model, but collapses the effects of multiple conceptually related variables into a single composite effect, aiding interpretation of model results. Finally, to aid final interpretation in light of this ability of SEM, we calculated the standardized total effects of land use intensity, climate, abiotic and biotic drivers on the diversity of soil bacteria. The net influence that one variable has upon another is calculated by summing all direct and indirect pathways between the two variables. If the model fits the data well, the total effect should approximate be the bivariate correlation coefficient for that pair of variables.

\section{Distance-based multimodel inference.}

To examine whether observed effects of resource quantity (total C, N and P) and stoichiometry (N:P, $\mathrm{C}: \mathrm{P}$ and $\mathrm{C}: \mathrm{N}$ ratios) were important compared to those of land use and other environmental factors (i.e. climate, microbial biomass, root influence, spatial heterogeneity and soil $\mathrm{pH}$ ) as drivers of bacterial diversity, we used a multi-model inference approach based on information theory and non-parametric distance-based linear regressions (DISTLM; McArdle and Anderson 2001). In particular, this analysis provided insights on whether the inclusion of resource quantity and stoichiometry in our models offer additional explanatory power to predict diversity of soil bacteria after accounting for other important land use and environmental factors. The Euclidean distance was used as the measure of dissimilarity 
between pairs of samples. We ranked top five models that could be generated with our independent variables according to the second-order Akaike information criterion (AICc). The lower the AICc index the better the model. Here, we consider a $\triangle \mathrm{AICc}>2$ threshold to differentiate between two substantially different models and then select the best of those models (Burnham and Anderson 2002; Burnham et al., 2011). Then, we compared the AICc of the best model which presumably includes resource quantity and stoichiometry to that of the corresponding model without resource quantity and stoichiometry. Differences $<2.0$ in AICc between alternative models indicate that they are approximately equivalent in explanatory power (Burnham and Anderson 2002; Burnham et al., 2011). We conducted distance-based multimodel inference with the PRIMER v6 statistical package for Windows (PRIMER-E Ltd., Plymouth Marine Laboratory, UK).

\section{Variation partitioning modeling.}

The variance partitioning linked to resource quantity (total $C, N$ and $\mathrm{P}$ ) and stoichiometry (N:P, C:P and $\mathrm{C}: \mathrm{N}$ ratios), land use (a categorical continuous variable with two levels: 0 (low intensity of human management: bog, moorland, forest and semi-natural grassland and 1 (high intensity of human management: improved grassland and arable) and other environmental factors (i.e. climate, microbial biomass, root influence, spatial heterogeneity and soil $\mathrm{pH}$ ) on bacterial diversity and community composition (at the OTU level) was calculated using the package vegan from R package (Tedersoo et al., 2014; Oksanen et al., 2015). The main goal of these analyses was to quantify the relative importance of resource quantity and stoichiometry vs. land use and other environmental variables as predictors of bacterial diversity and community composition. In particular, this analysis provided insights on whether resource quantity and stoichiometry can explain a unique portion of the variance, which is not explained by other predictors.

\section{Distance-based Redundancy Analysis (db-RDA).}

We use db-RDA to explore the effects of human management, temperature, precipitation, $\mathrm{pH}$, spatial heterogeneity, total $\mathrm{C}, \mathrm{N}, \mathrm{P}, \mathrm{C}: \mathrm{N}$ ratio, $\mathrm{N}$ : $\mathrm{P}$ ratio, $\mathrm{C}$ : $\mathrm{P}$ ratio, microbial biomass, root development on bacterial diversity (based on bacterial composition at OTUs level). We conducted db-RDA with the PRIMER v6 statistical package for Windows (PRIMER-E Ltd., Plymouth Marine Laboratory, UK), using the Bray-Curtis similarity.

\section{Conflict of interest}

The authors declare no conflict of interest. 


\section{Acknowledgments}

This research is supported by the ARC project DP13010484. CDC and NT were funded by the Scottish Government. The work of the Soil Survey of Scotland team and analytical staff at the James Hutton Institute are acknowledged for the use of samples and data in the Soil Inventory. We also acknowledge C. Cameron, E. Reid, and A. Main for their contribution to laboratory analyses. Finally, we also thank Jasmine Grinyer and Melissa S. Martin for revising the English of this manuscript.

\section{Additional information}

Supplementary information is available in the online version of the paper.

\section{References}

Adams, C.R., Bamford, K.M. and Early, M.P. Principles of Horticulture (Routledge, Abingdon, UK, 2012).

Andam, C.P., Doroghazi, J.R., Campbell, A.N., Kelly, P.J., Choudoir, M.J., Buckley, D.H. A latitudinal diversity gradient in terrestrial bacteria of the genus Streptomyces. mBio 7, e0220015 (2016).

Anderson, M.J. A new method for non-parametric multivariate analysis of variance. Austral Ecology 26, 32-46 (2001).

Bardgett, R. and McAlister, E. The measurement of soil fungal: bacterial biomass ratios as an indicator of ecosystem self-regulation in temperate meadow grasslands. Biol. Fert. Soils, 29, 282-290 (1999).

Bardgett, R.D., Usher, M.B. and Hopkins, D.W. Biological Diversity and Function in Soils (Cambridge: Cambridge University Press 2005).

Bardgett, R.D. and van der Putten, W.H. Belowground biodiversity and ecosystem functioning. Nature 515, 505-511 (2014).

Battistuzzi, F.U. and Hedges, S.B. Major clade of prokaryotes with ancient adaptations to life on land. Mol. Biol. Evol. 26, 335-43 (2009).

Bragg, L. et al., Fast, accurate error-correction of amplicon pyrosequences using Acacia. Nature Methods 9, 425-426 (2012).

Burnham, K.P. and Anderson, D.R. Model Selection Multimodel Inference A Practical InformationTheoretic Approach second edition (Springer, NY, USA, 2002). 
Burnham, K.P., Anderson, D.R. and Huyvaert. K.P. AIC model selection and multimodel inference in behavioral ecology: some background, observations, and comparisons. Behav. Ecol. Sociobiol. 65, 23-35 (2011).

Campbell C.D. et al., A Rapid Microtiter Plate Method To Measure Carbon Dioxide Evolved from Carbon Substrate Amendments so as To Determine the Physiological Profiles of Soil Microbial Communities by Using Whole Soil. Appl. Environ. Microbiol. 69, 3593 (2003).

Delgado-Baquerizo, M. et al., Decoupling of soil nutrient cycles as a function of aridity in global drylands. Nature 502, 672-676 (2013).

Delgado-Baquerizo, M. et al., (2016a). Microbial diversity drives multifunctionality in terrestrial ecosystems. Nat. Commun. 7, 10541.

Delgado-Baquerizo, M. et al., (2016b). Carbon content and climate variability drive global soil bacterial diversity patterns. Ecol. Monogr. 86, 373-380.

De Vries, F.T. et al., Abiotic drivers and plant traits explain landscape-scale patterns in soil microbial communities. Ecol. Lett. 15, 1230-1239 (2012).

Fierer, N. et al., Global patterns in belowground communities. Ecol. Lett. 12, 1238-1249 (2009).

Grace, J.B. Structural Equation Modeling Natural Systems (Cambridge University Press, New York, USA, 2006).

Haegeman, B. et al., 2013 Robust estimation of microbial diversity in theory and in practice. Robust estimation of microbial diversity in theory and in practice. The ISME Journal 7, 1092-1101.

Herlemann, D.P. et al.,, Biogeography of bacterial communities exposed to progressive long-term environmental change. The ISME journal 5, 1571-1579 (2011).

Hijmans RJ et al (2005) Very high resolution interpolated climate surfaces for global land areas. Int. J. of Climatol. 25, 1965-1978.

Hooper, D.U. et al., Interactions between aboveground and belowground biodiversity in terrestrial ecosystems: patterns, mechanisms, and feedbacks. BioScience 50, 1049-1061 (2000).

Horner-Devine, M.C. et al., A taxa-area relationship for bacteria. Nature 432, 750-753 (2004).

Jangid, K. et al., Soil bacterial community succession during long-term ecosystem development. Mol. Ecol. 22, 3415-3424 (2014).

Jing, X. et al., (2015). The links between ecosystem multifunctionality and above- and belowground biodiversity are mediated by climate. Nat. Commun. 6, 8159 .

Lauber, C.L. et al., Pyrosequencing-based assessment of soil $\mathrm{pH}$ as a predictor of soil bacterial community structure at the continental scale. Appl. Environ. Microbiol. 75, 5111-20 (2009).

Wiley-Blackwell and Society for Applied Microbiology

This article is protected by copyright. All rights reserved. 
Lilly, A et al., National Soil Inventory of Scotland 1 (NSIS_1): site location, sampling and profile description protocols (1978- 1988). Technical Bulletin, Macaulay Institute (2010).

Maestre, F.T. et al., (2015) Increasing aridity reduces soil microbial diversity and abundance in global drylands. Proc. Natl Acad. Sci. USA 112, 15684-15689.

McArdle, B.H. and Anderson, M.J. Fitting multivariate models to community data: a comment on distance-based redundancy analysis, Ecology 82, 290-297 (2001).

McCune, B. and Grace, J.B. Analysis of Ecological Communities (MjM Software, Gleneden Beach, Oregon, USA, 2002).

McGill, W.B. and Cole, C.V. Comparative aspects of cycling organic C, N, S. and P through soil organic matter. Geoderma 26, 267-28 (1981).

McGrath, S.P. and Loveland, P.J. The Soil Geochemical Atlas of England and Wales (Blackie, London, 1992).

Oksanen, J., Blanchet F.G., Kindt R., Legendre, P., Minchin, P.R., O'Hara, R.B., Simpson, G.L., Solymos, P., Henry, M., Stevens H., Wagner H. vegan: Community Ecology Package. R package version 2.3-0 (2015).

Paterson, E., Clark, L. and Birnie, A.C. Sequential selective dissolution of iron, aluminium and silicon from soils. Commun. Soil Sci. Plan. 24, 2015-2023 (1993).

Peñuelas, J. and Sardans J. Elementary factors. Nature 460, 803-804 (2009).

Peñuelas, J. et al., The human-induced imbalance between C, N and P in Earth's life system. Glob. Change Biol. 18, 3-6 (2012).

Tilman, D. Resource Competition and Community Structure (Princeton University Press, Princeton, NJ. 1982).

Ranjard, L. et al., Turnover of soil bacterial diversity driven by wide-scale environmental heterogeneity. Nature Comm. 4, doi:10.1038/ncomms2431 (2013).

Sardans, J. et al., The elemental stoichiometry of aquatic and terrestrial ecosystems and its relationships with organismic lifestyle and ecosystem structure and function: a review and perspectives. Biogeochemistry 111, 1-39 (2012).

Schermelleh-Engel, K. et al., Evaluating the fit of structural equation models, tests of significance descriptive goodness-of-fit measures. Methods of Psychological Research Online 8, 23-74 (2003).

Smith, B.F.L. and Bain D.C. A sodium fusion method for the determination of total phosphate in soils. Commun. Soil Sci. Plan. 13, 185-190 (1982). 
Sterner, R.W. and Elser, J.J. Ecological Stoichiometry: The Biology of Elements from Molecules to the Biosphere (Princeton Univ. Press, 2002).

Tedersoo, L. et al., Global diversity and geography of soil fungi. Science 346, 6213 (2014).

Trivedi, P., Anderson I.C. and Singh, B.K. Microbial modulators of soil carbon storage: integrating genomic and metabolic knowledge for global prediction. Trends in Microbiol. 21, 641-651 (2013).

van der Heijden, M.G.A. et al., The unseen majority: soil microbes as drivers of plant diversity and productivity in terrestrial ecosystems. Ecol. Lett. 11, 296-310 (2008).

Waldrop, M.P. et al., Resource availability controls fungal diversity across a plant diversity gradient. Ecol. Lett. 9, 1127-1135 (2006).

Wall, D.H., Bardgett, R.D. and Kelly, E.F. Biodiversity in the dark. Nature Geosci. 3, 297-298 (2010).

Wardle, D. A. The influence of biotic interactions on soil biodiversity. Ecol. Lett. 9, 870-886 (2006).

Xu, X., Thornton, P. E. and Post, W. M. A global analysis of soil microbial biomass carbon, nitrogen and phosphorus in terrestrial ecosystems. Global Ecol. Biogeogr. 22, 737-749 (2013).

Zechmeister-Boltenstern, S. et al., The application of ecological stoichiometry to plant-microbial-soil organic matter transformations. Ecol. Monogr. 85, 133-155 (2015).

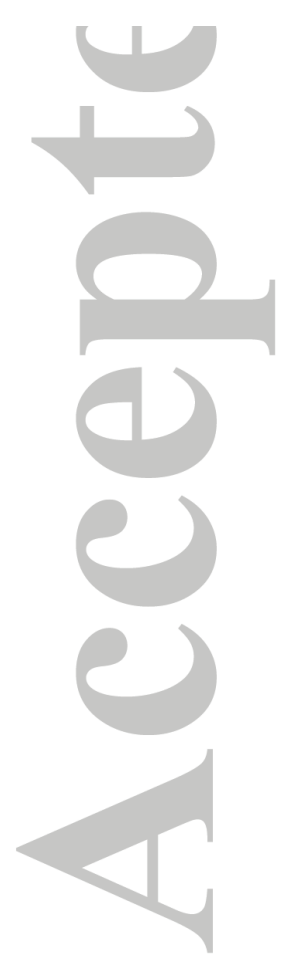




\section{Figure Legends}

Figure 1. Conceptual framework exploring the effects of land use intensity and nutrient stoichiometry on the diversity of soil bacteria. Land use intensity alters C:N:P stoichiometry. Cultivation reduces organic matter (organic $\mathrm{C}$ and total $\mathrm{N}$ ) but brings back the bedrock via erosion (total P). Fast-growing organisms such as bacteria require high P to support high growth rates (i.e. ATP, DNA and RNA) and are characterized by low C:P ratios. In this respect, if diversity mirrors productivity within bacterial communities, P supply might drive bacterial diversity. Places with high P may support a high microbial diversity as microbes can fulfill their partial $\mathrm{C}$ and $\mathrm{N}$ requirement fixing these elements from atmosphere (i.e. C, $\mathrm{N}$ and $\mathrm{P}$ are available for microbes). However, places with low $\mathrm{P}$ lessen bacterial diversity as a consequence of the competition-to-exclusion driven via $\mathrm{P}$ which is coming almost exclusively from the bedrock (i.e. only $\mathrm{C}$ and $\mathrm{N}$ are available for microbes).

Figure 2. Relationships between $\mathrm{C}, \mathrm{N}$ and $\mathrm{P}$ availabilities and ratios and the soil bacterial diversity in our study sites. $\mathrm{P}$ values were calculated using a distance-based linear model (DISTLM) from PERMANOVA.

Figure 3. Structural equation modeling on the direct (a) and total (b) effects of climate (MAT and MAP), land use, organic matter (Total $\mathrm{C}$ and $\mathrm{N}$ ), total $\mathrm{P}$, plant root, microbial biomass, soil $\mathrm{pH}$, soil spatial heterogeneity on bacterial diversity. Numbers adjacent to arrows are standardized path coefficients, analogous to relative regression weights, and indicative of the effect size of the relationship. Continuous and dashed arrows indicate positive and negative relationships, respectively. The width of arrows is proportional to the strength of path coefficients. The proportion of variance explained $\left(\mathrm{R}^{2}\right)$ appears above every response variable in the model. Climate is included as two independent observable variables in the model, however we group them in the same box in the model for graphical simplicity. Goodness-of-fit statistics for each model are shown in the lower right corner. Hexagons are composite variables. Squares are observable variables. Significance levels are as follows: $* \mathrm{P}<0.05, * * \mathrm{P}<0.01$ and $* * * \mathrm{P}<0.001$. MAP $=$ mean annual precipitation. MAT $=$ mean annual temperature.

Figure 4. Relative contribution of resource quantity and stoichiometry, land use and other environmental factors as predictors of bacterial diversity and community composition at the OTU level. Panels represent results from variation partitioning modelling aiming to identity the percentage variance of bacterial bacterial diversity and community composition explained by resource quantity and stoichiometry, land use and other environmental factors. Shared effects of these variable groups are indicated by the overlap of circles. 
Figure 5. Selected relationships between $\mathrm{C}: \mathrm{P}$ and $\mathrm{C}: \mathrm{N}$ ratios with the relative abundance of main bacterial groups in this study. P values were calculated using a distance-based linear model (DISTLM) from PERMANOVA. Correlations (Spearman) between C, N, P availability and ratios and bacterial groups are available in Table S2.

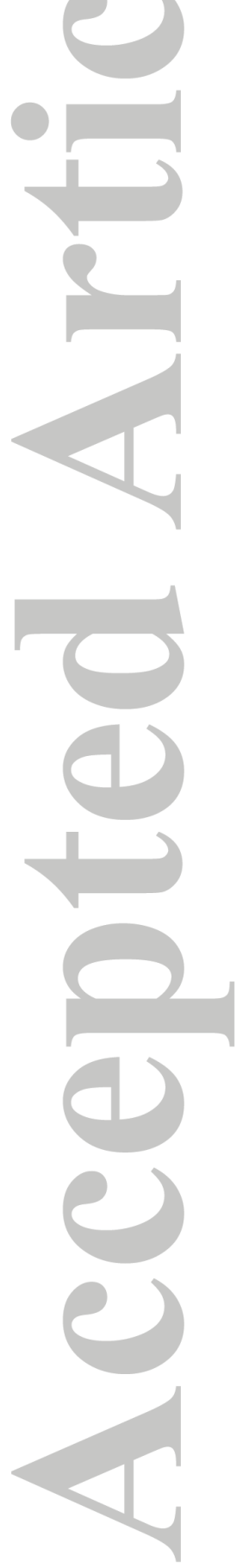




\section{Supporting information}

Additional Supporting Information may be found in the online version of this article at the publisher's website:

Appendix S1. Supplementary Methods

Figure S1. Relationships between total C, N and P and between C:P, N:P and C:P. Solid lines represent the fitted linear regressions $(n=179) . P$ values were calculated using a distance-based linear model (DISTLM) from PERMANOVA.

Figure S2. Relationships between total C, N and P (i.e. uncorrected by bulk density) with the diversity of soil bacteria. Solid lines represent the fitted linear regressions $(n=179)$. P values were calculated using a distance-based linear model (DISTLM) from PERMANOVA.

Figure S3. Relationships between $\mathrm{C}, \mathrm{N}$ and $\mathrm{P}$ availabilities and ratios and the residuals of bacterial diversity (residuals of the relationship between soil depth and bacterial diversity) in our study sites. $\mathrm{P}$ value were calculated using a distance-based linear model (DISTLM) from PERMANOVA.

Figure S4. Alternative a priori model (for SEM) including bulk density and uncorrected values of total C, N and P (e.g. by bulk density). This model evaluated the effects of land use intensity, bulk density, climate, organic matter (total $\mathrm{C}$ and $\mathrm{N}$ ), total $\mathrm{P}$, soil $\mathrm{pH}$, plant roots, microbial biomass and soil spatial heterogeneity on the diversity of soil bacteria. There are some differences between the a priori model and the final model structures due to the removal of paths with coefficients close to zero (see Fig. S4). $\mathrm{MAP}=$ mean annual precipitation. MAT $=$ mean annual temperature.

Figure S5. Alternative structural equation modeling considering the effects of bulk density, climate (MAT and MAP), land use intensity, organic matter (Total C and N), total P, plant root, microbial biomass, soil $\mathrm{pH}$, soil spatial heterogeneity on bacterial diversity. Numbers adjacent to arrows are standardized path coefficients, analogous to relative regression weights, and indicative of the effect size of the relationship. Continuous and dashed arrows indicate positive and negative relationships, respectively. The width of arrows is proportional to the strength of path coefficients. The proportion of variance explained (R2) appears above every response variable in the model. Climate is included as two independent observable variables in the model, however we group them in the same box in the model for graphical simplicity. Goodness-of-fit statistics for each model are shown in the lower right corner. Hexagons are composite variables. Squares are observable variables. Significance levels are as follows: $\mathrm{aP}<0.10,{ }^{*} \mathrm{P}<0.05,{ }^{* *} \mathrm{P}<0.01$ and $* * * \mathrm{P}<0.001$. MAP $=$ mean annual precipitation. $\mathrm{MAT}=$ mean annual temperature. 
Figure S6. Mean values for total $\mathrm{C}, \mathrm{N}$ and $\mathrm{P}$ and $\mathrm{C}: \mathrm{P}, \mathrm{N}: \mathrm{P}$ and $\mathrm{C}: \mathrm{N}$ ratios among different land uses: arable $(n=17)$, improved grassland $(n=28)$, semi-natural grassland $(n=32)$, woodland $(n=29)$, moorland $(\mathrm{n}=39)$ and bog $(\mathrm{n}=34)$. Bar graphs represent means and SE. We used PERMANOVA analyses to test for significant differences among land uses $(\mathrm{n}=179)$ including soil depth as a covariable in these analyses. Different letters in these figures indicate significant differences among land uses $(\mathrm{P}<0.05$, post-hoc test after PERMANOVA analyses). Semi-natural $\mathrm{g}$. = semi-natural grassland; improved g. = improved grassland. Dark and white bars indicate low and high intensity human management, respectively.

Figure S7. Mean values for soil bacterial diversity among different land uses: arable $(\mathrm{n}=17)$, improved grassland $(n=28)$, semi-natural grassland $(n=32)$, woodland $(n=29)$, moorland $(n=39)$ and $\operatorname{bog}(n=34)$. Bar graphs represent means and SE. We used PERMANOVA analyses to test for significant differences among land uses $(n=179)$ including soil depth as a co-variable in these analyses. Different letters in these figures indicate significant differences among land uses $(\mathrm{P}<0.05$, post-hoc test after PERMANOVA analyses). Semi-natural g. = semi-natural grassland; improved g. $=$ improved grassland. Dark and white bars indicate low and high intensity human management, respectively.

Figure S8. db-RDA ordination exploring the effects of, mean annual temperature (MAT), mean annual precipitation (MAP), $\mathrm{pH}$, spatial heterogeneity, total $\mathrm{C}, \mathrm{N}, \mathrm{P}, \mathrm{C}: \mathrm{N}$ ratio, $\mathrm{N}: \mathrm{P}$ ratio, $\mathrm{C}: \mathrm{P}$ ratio, microbial biomass, root development on bacterial diversity across different land uses.

Figure S9. Relative abundance of the main bacteria phyla in this study among different land uses: arable $(\mathrm{n}=17)$, improved grassland $(\mathrm{n}=28)$, semi-natural grassland $(\mathrm{n}=32)$, woodland $(\mathrm{n}=29)$, moorland $(\mathrm{n}=39)$ and bog $(\mathrm{n}=34)$.

Figure S10. Structural equation modeling exploring the effects of climate (MAT and MAP), land use, organic matter (Total $\mathrm{C}$ and $\mathrm{N}$ ), total $\mathrm{P}$, plant root, microbial biomass, soil $\mathrm{pH}$, soil spatial heterogeneity on selected microbial taxa. Numbers adjacent to arrows are standardized path coefficients, analogous to relative regression weights, and indicative of the effect size of the relationship. Continuous and dashed arrows indicate positive and negative relationships, respectively. The width of arrows is proportional to the strength of path coefficients. The proportion of variance explained (R2) appears above every response variable in the model. Climate is included as two independent observable variables in the model, however, we group them in the same box in the model for graphical simplicity. Goodness-of-fit statistics for each model are shown in the lower right corner. 
Hexagons are composite variables. Squares are observable variables. Significance levels are as follows: $* \mathrm{P}<0.05, * * \mathrm{P}<0.01$ and $* * * \mathrm{P}<0.001$. MAP $=$ mean annual precipitation. $\mathrm{MAT}=$ mean annual temperature.

Figure S11. Standardized total effects (direct plus indirect effects) derived from the structural equation modeling, including the effects climate (MAT and MAP), land use, organic matter (Total C and N), total $\mathrm{P}$, plant root, microbial biomass, soil $\mathrm{pH}$, soil spatial heterogeneity on selected microbial taxa.

Figure S12. Mean values for bulk density among different land uses: arable $(\mathrm{n}=17)$, improved grassland $(\mathrm{n}=28)$, semi-natural grassland $(\mathrm{n}=32)$, woodland $(\mathrm{n}=29)$, moorland $(\mathrm{n}=39)$ and bog $(\mathrm{n}=$ 34). Bar graphs represent means and SE. We used PERMANOVA analyses to test for significant differences among land uses $(n=179)$ including soil depth as a co-variable in these analyses. Different letters in these figures indicate significant differences among land uses $(\mathrm{P}<0.05$, post-hoc test after PERMANOVA analyses). The number of samples in each land use is: Semi-natural g. = semi-natural grassland; improved g. = improved grassland. Dark and white bars indicate low and high intensity human management, respectively.

Figure S13. a priori model (for SEM) used in this study. Our model evaluated the effects of land use intensity, climate, organic matter (total $\mathrm{C}$ and $\mathrm{N}$ ), total $\mathrm{P}$, soil $\mathrm{pH}$, plant roots, microbial biomass and soil spatial heterogeneity on the diversity of soil bacteria. There are some differences between the a priori model and the final model structures owing to the removal of paths with coefficients close to zero (see Fig. 3). MAP = mean annual precipitation. MAT = mean annual temperature.

Figure S14. Rarefaction curves for bacterial diversity (Shannon, bits). Lines represent different soil samples.

Table S1. Top five best-fitting models and the same models without resource quantity and stoichiometry. Shaded cells indicate that the variable has been included in the model. Models are ranked by AICc. AICc measures the relative goodness of fit of a given model; the lower its value, the more likely the model to be correct. $\triangle \mathrm{AICc}$ are difference between the AICc of each model and that of the best model. MAT $=$ Mean annual temperature; MAP = Mean annual precipitation; Soil heterogeneity $=$ Soil spatial heterogeneity.

Table S2. Correlation coefficients (Spearman's $\rho$ ) between different C:N:P availabilities and ratios with the relative abundance of the main bacteria phyla and Proteobacteria classes in this study.

Table S3. Correlation coefficients (Spearman's $\rho$ ) between different total nutrients and $\mathrm{pH}$ in this study. P-values in brackets.

Wiley-Blackwell and Society for Applied Microbiology

This article is protected by copyright. All rights reserved. 
Page 36 of 40

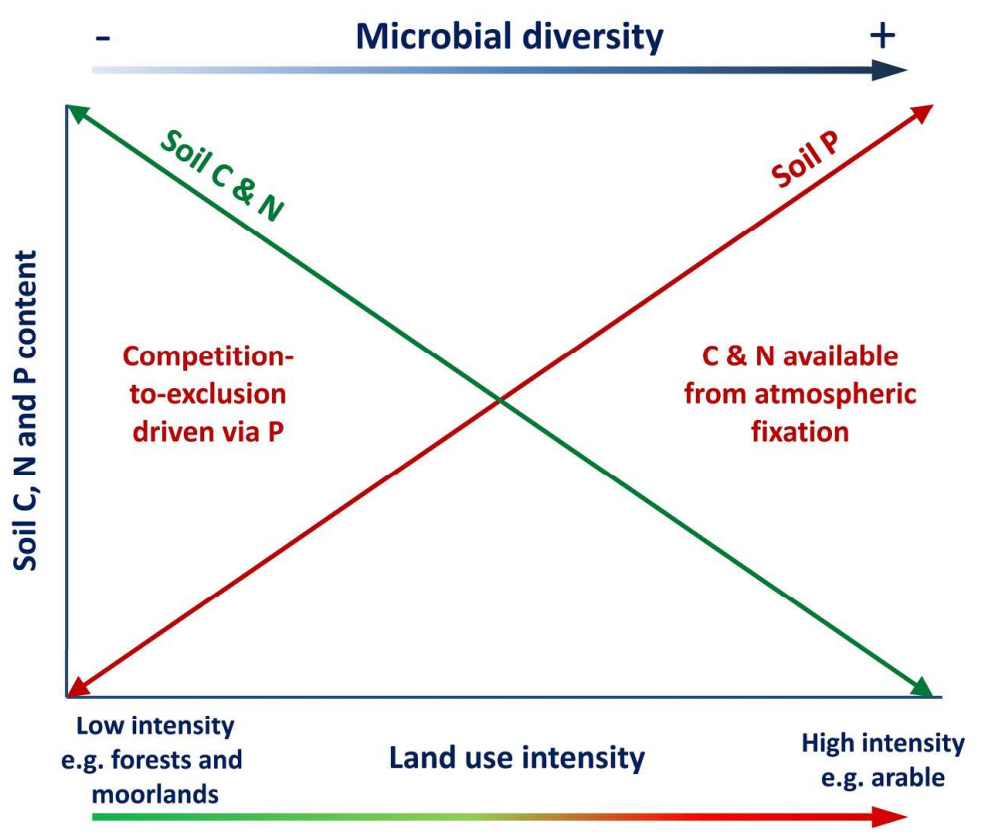

Figure 1. Conceptual framework exploring the effects of land use intensity and nutrient stoichiometry on the diversity of soil bacteria. Land use intensity alters C:N:P stoichiometry. Cultivation reduces organic matter (organic $\mathrm{C}$ and total $\mathrm{N}$ ) but brings back the bedrock via erosion (total $\mathrm{P}$ ). Fast-growing organisms such as bacteria require high $\mathrm{P}$ to support high growth rates (i.e. ATP, DNA and RNA) and are characterized by low $C: P$ ratios. In this respect, if diversity mirrors productivity within bacterial communities, $P$ supply might drive bacterial diversity. Places with high $\mathrm{P}$ may support a high microbial diversity as microbes can fulfill their partial $\mathrm{C}$ and $\mathrm{N}$ requirement fixing these elements from atmosphere (i.e. $\mathrm{C}, \mathrm{N}$ and $\mathrm{P}$ are available for microbes). However, places with low $\mathrm{P}$ lessen bacterial diversity as a consequence of the competition-toexclusion driven via $\mathrm{P}$ which is coming almost exclusively from the bedrock (i.e. only $\mathrm{C}$ and $\mathrm{N}$ are available for microbes).

$209 \times 148 \mathrm{~mm}(300 \times 300 \mathrm{DPI})$

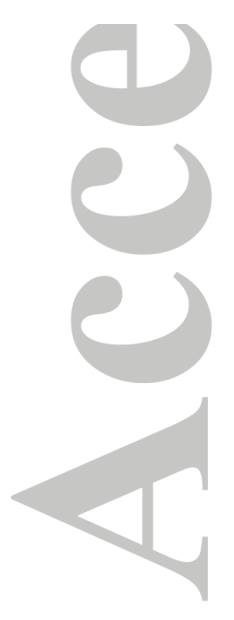

Wiley-Blackwell and Society for Applied Microbiology

This article is protected by copyright. All rights reserved. 
a)

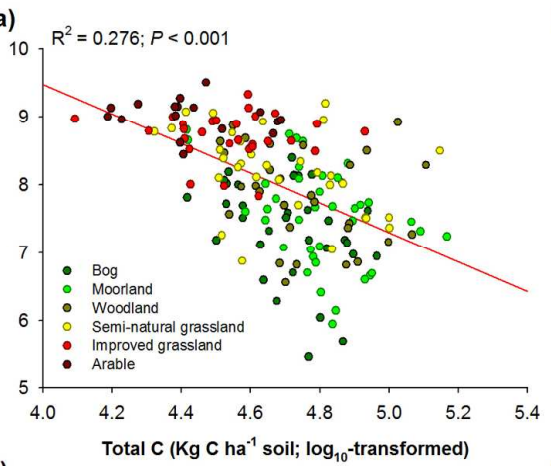

c)
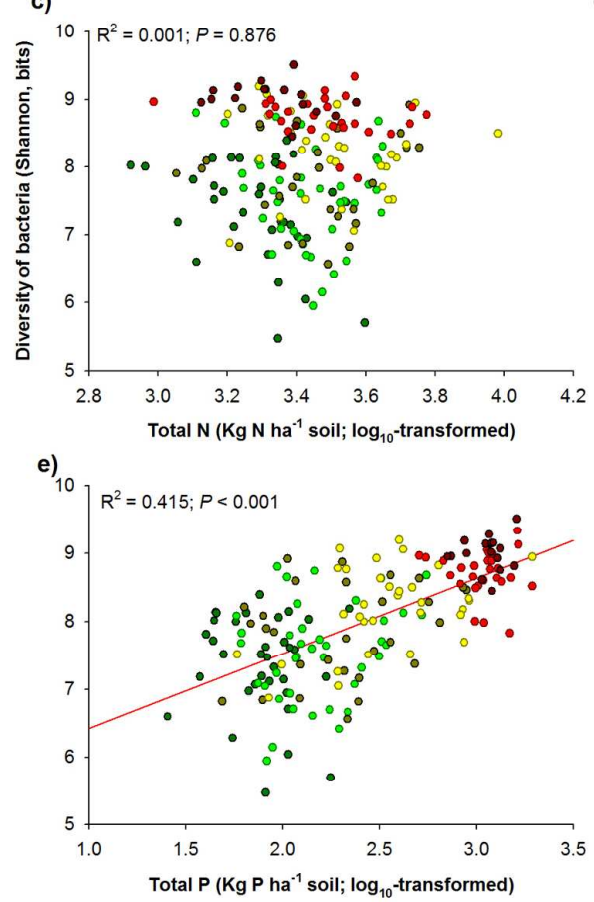

b) $R^{2}=0.507: P<0.001$

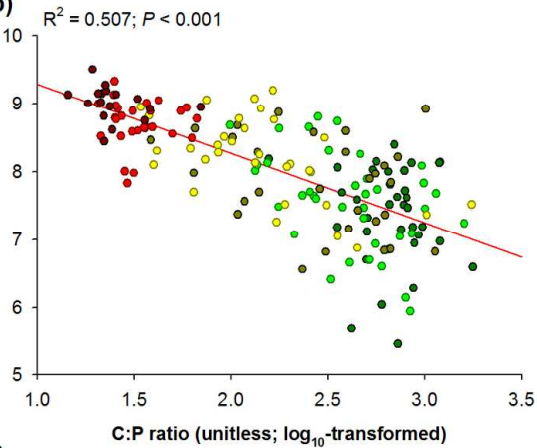

d)
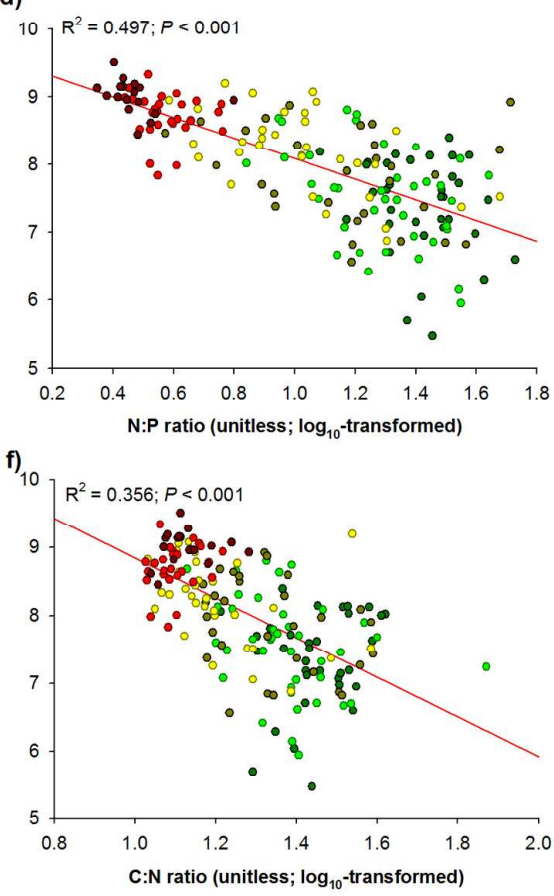

Figure 2. Relationships between $\mathrm{C}, \mathrm{N}$ and $\mathrm{P}$ availabilities and ratios and the soil bacterial diversity in our study sites. $P$ values were calculated using a distance-based linear model (DISTLM) from PERMANOVA.

$316 \times 360 \mathrm{~mm}(150 \times 150 \mathrm{DPI})$

Wiley-Blackwell and Society for Applied Microbiology

This article is protected by copyright. All rights reserved. 


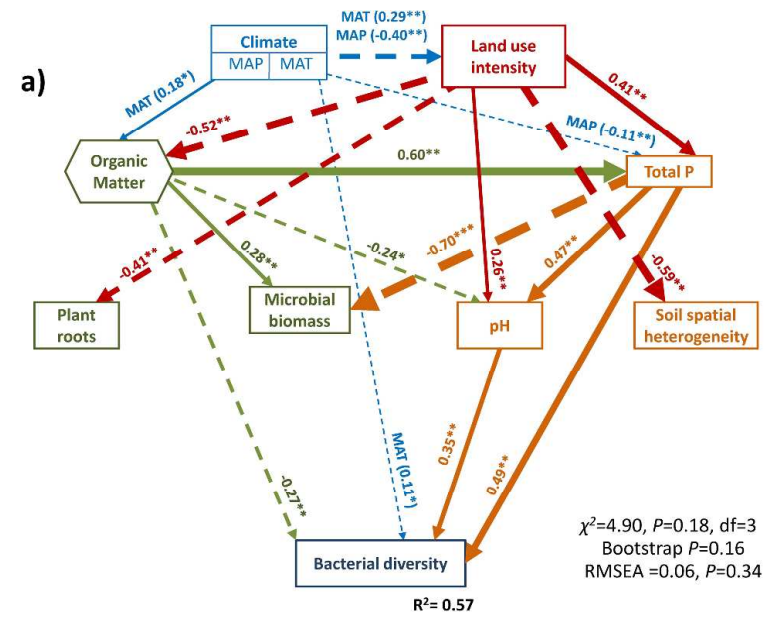

b)

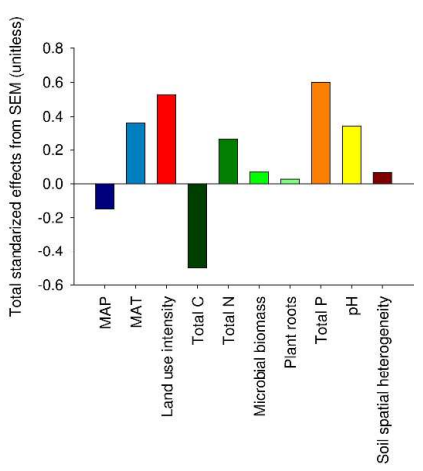

Figure 3. Structural equation modeling on the direct (a) and total (b) effects of climate (MAT and MAP), land use, organic matter (Total $\mathrm{C}$ and $\mathrm{N}$ ), total $\mathrm{P}$, plant root, microbial biomass, soil $\mathrm{pH}$, soil spatial heterogeneity on bacterial diversity. Numbers adjacent to arrows are standardized path coefficients, analogous to relative

regression weights, and indicative of the effect size of the relationship. Continuous and dashed arrows

indicate positive and negative relationships, respectively. The width of arrows is proportional to the strength of path coefficients. The proportion of variance explained (R2) appears above every response variable in the model. Climate is included as two independent observable variables in the model, however we group them in the same box in the model for graphical simplicity. Goodness-of-fit statistics for each model are shown in the lower right corner. Hexagons are composite variables. Squares are observable variables. Significance levels are as follows: $* \mathrm{P}<0.05, * * \mathrm{P}<0.01$ and $* * * \mathrm{P}<0.001$. MAP $=$ mean annual precipitation. MAT $=$ mean annual temperature. 
a)

Diversity

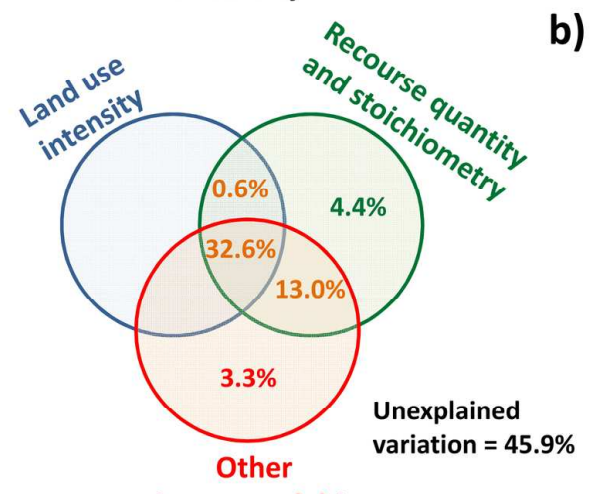

environmental drivers
Composition

)

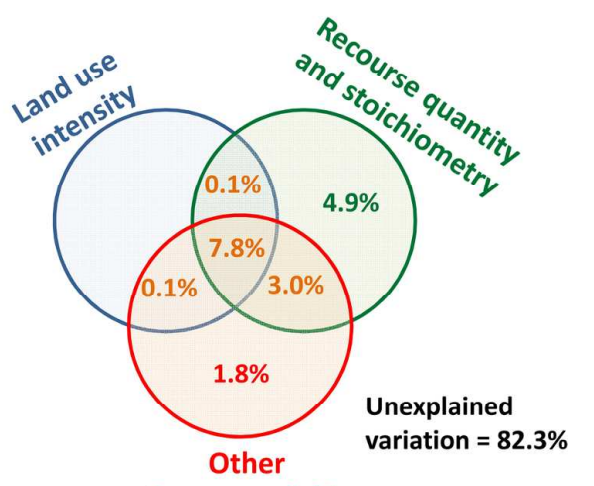

environmental drivers

Figure 4. Relative contribution of resource quantity and stoichiometry, land use and other environmental factors as predictors of bacterial diversity and community composition at the OTU level. Panels represent results from variation partitioning modelling aiming to identity the percentage variance of bacterial bacterial diversity and community composition explained by resource quantity and stoichiometry, land use and other environmental factors. Shared effects of these variable groups are indicated by the overlap of circles.

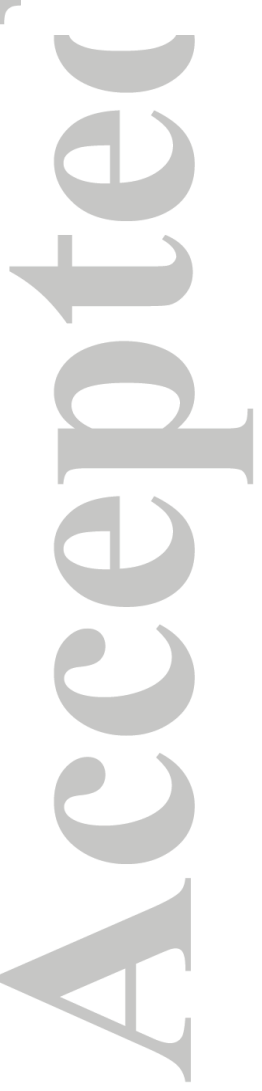

$86 \times 39 \mathrm{~mm}(600 \times 600 \mathrm{DPI})$ 

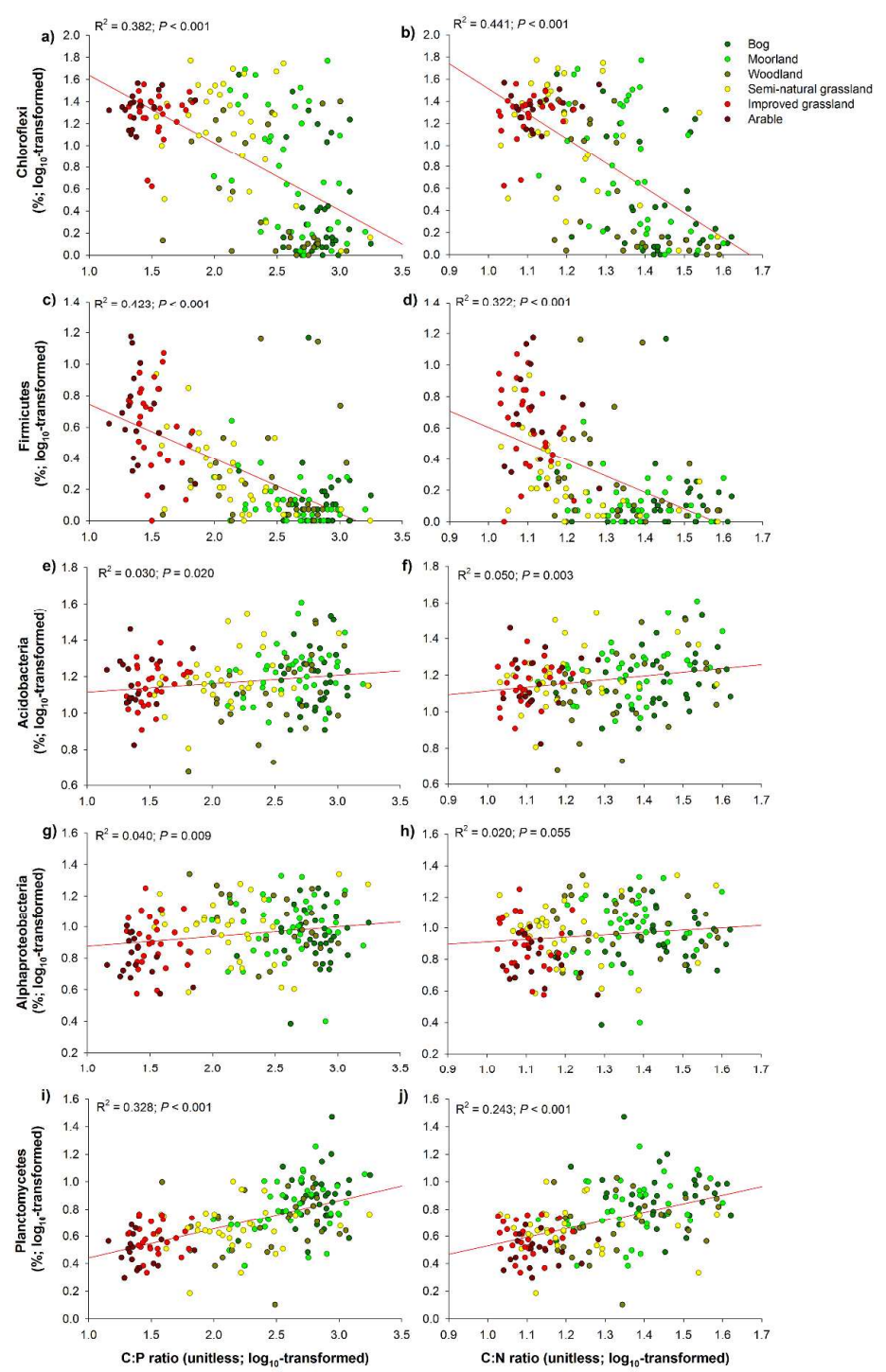

Figure 5. Selected relationships between $\mathrm{C}: \mathrm{P}$ and $\mathrm{C}: \mathrm{N}$ ratios with the relative abundance of main bacterial groups in this study. $P$ values were calculated using a distance-based linear model (DISTLM) from PERMANOVA. Correlations (Spearman) between C, N, P availability and ratios and bacterial groups are available in Table S2.

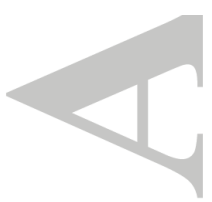

$356 \times 555 \mathrm{~mm}(300 \times 300$ DPI $)$

\section{Wiley-Blackwell and Society for Applied Microbiology}

This article is protected by copyright. All rights reserved. 